Economics Development Analysis Journal 5(3)(2016)

\title{
Kesenjangan Fasilitas Publik antar Kabupaten/Kota Dan Kaitannya dengan Pusat Pertumbuhan
}

\author{
Wontiana $^{1 凶}$, ST Sunarto ${ }^{2}$ \\ ${ }^{1}$ Jurusan Ekonomi Pembangunan, Fakultas Ekonomi, Universitas Negeri Semarang \\ ${ }^{2}$ STIE Semarang, Jawa Tengah
}

\section{Info Artikel Abstrak}

Sejarah Artikel:

Diterima Juni 2016

Disetujui Juli 2016

Dipublikasikan Agustus 2016

\section{Keywords:}

Public Facilities Disparities, Growth Pole, Schallogram, centrality index analysis

\begin{abstract}
Salah satu indikator kesenjangan kemakmuran daerah dapat dilihat dari perbedaan jumlah dan jenis fasilitas publik yang terdapat dimasing-masing daerah. Ketidakmerataan penyebaran sumber daya dan pembangunan fasilitas sosial ekonomi menyebabkan pertumbuhan wilayah juga tidak merata, sehingga diperlukan adanya daerah-daerah yang dapat menjadi pusat pertumbuhan. Penelitian ini bertujuan untuk menganalisis tingkat kesenjangan fasilitas publik di Provinsi Jawa Tengah dan kabupaten/kota yang berpotensi menjadi pusat pertumbuhan di masing-masing kawasan strategis Provinsi Jawa Tengah. Data yang digunakan adalah data sekunder fasilitas publik di 35 kabupaten/kota Provinsi Jawa Tengah yang diperoleh dari Badan Pusat Statistik. Metode analisis yang digunakan yaitu analisis deskriptif, analisis skalogram dan indeks sentralitas marshal. Hasil penelitian menunjukkan kesenjangan fasilitas publik di Provinsi Jawa Tengah rendah. Pusat pertumbuhan di masing-masing kawasan strategis Provinsi Jawa Tengah adalah Kedung Sepur: Kota Semarang dan Kota Salatiga, Barlingmascakep: Kabupaten Cilacap dan Kabupaten Banyumas, Purwomanggung: Kota Magelang dan Kabupaten Wonosobo, Subosukowonosraten: Kabupaten Sukoharjo dan Kabupaten Klaten, Banglor: Kabupaten blora, Wanarakuti: Kabupaten Jepara dan Kabupaten Pati, Tangkallangka: Kota Pekalongan dan Kabupaten Pemalang, Bregas: Kota Tegal.
\end{abstract}

\begin{abstract}
One of the indicator of regional disparities in prosperity could be seen from the difference in the number and types of public facilities contained in each regions. Inequality deployment of resources and socio-economic development of the facility led to the growth of the region was also uneven, so, it is requires some areas that can become the center of growth. The purpose of this study is to analyze the inequality of public facilities in Central Java and the districts / cities that potentially could become the center of growth in each strategic region of Central Java. the data used is secondary data of public facilities in 35 districts / cities in Central Java from The Central Statistic Board. A method of study using descriptive analysis through SPSS, Schallogram analysis, and centrality index analysis. The results showed that the public facilities disparities is low. Center of growth in each strategic region of Central Java is Kedung Sepur: Semarang City and Salatiga, Barlingmascakep: Cilacap and Banyumas, Purwomanggung: Magelang City and Wonosobo, Subosukowonosraten: Sukoharjo and Klaten, Banglor: Blora, Wanarakuti: Jepara and Pati, Tangkallangka: Pekalongan City and Pemalang, Bregas: Tegal City.
\end{abstract}

Ruang Jurnal,Gedung L FE UNNES Sekaran Gunungpati

Semarang 50229, Indonesia

E-mail: wontiana1502@gmail.com 


\section{PENDAHULUAN}

Desentralisasi merupakan penyerahan wewenang dari pemerintah pusat kepada pemerintah daerah untuk mengatur sendiri sumber daya yang dimiliki. Hal ini berkaitan dengan tanggung jawab pemerintah daerah untuk meningkatkan kesejahteraan masyarakat melalui pembangunan ekonomi yaitu menciptakan pertumbuhan ekonomi untuk mengurangi kemiskinan, pengangguran dan ketimpangan (Todaro, 1994:88).

Kunci keberhasilan sistem desentralisasi disuatu daerah bergantung pada kekhasan karakteristik daerah yang bersangkutan dengan memanfaatkan potensi yang dimiliki yang berkaitan dengan sumber daya manusia, kelembagaan, dan sumber daya fisik secara lokal. Perbedaan kondisi daerah membawa dampak yang berbeda disetiap daerah.

Peningkatan pertumbuhan ekonomi oleh setiap daerah akan menyebabkan terjadinya kesenjangan kemakmuran antar daerah. Hal ini disebabkan oleh perbedaan geografis, kondisi, dan sumber daya yang dimiliki setiap daerah. Perbedaan tersebut menyebabkan daerah yang memiliki potensi besar akan menjadi semakin maju, daerah yang memiliki potensi terbatas akan menjadi daerah yang terbelakang. Hal tersebut akan menimbulkan kesenjangan antar daerah semakin tinggi.

Menurut Kuncoro (2006), kesenjangan mengacu pada standar hidup relatif dari seluruh masyarakat, sebab kesenjangan antar wilayah yaitu adanya perbedaan faktor anugrah awal (endowment factor). Perbedaan ini yang menyebabkan tingkat pembangunan di berbagai wilayah dan daerah berbeda-beda, sehingga menimbulkan gap atau jurang kesejahteraan di berbagai wilayah tersebut.

Salah satu indikator kesenjangan kemakmuran daerah dapat dilihat dari perbedaan jumlah dan jenis fasilitas publik yang terdapat dimasing-masing daerah. Perbedaan dalam ketersediaan fasilitas publik dapat menunjukkan tingkat pertumbuhan yang berbeda di setiap daerah baik secara sosial maupun ekonomi.

Pada tabel 1 dibawah ini menunjukkan tahun 2013 terdapat perbedaan yang cukup jauh pada jumlah fasilitas publik antar kabupaten/kota di Provinsi Jawa Tengah. Ratarata jumlah fasilitas publik di Provinsi Jawa Tengah sebanyak 5.466 unit, namun terdapat daerah dengan jumlah fasilitas publik yang jauh diatas rata-rata yaitu Kabupaten Cilacap sebanyak 9.414 unit dan terdapat juga daerah dengan jumlah fasilitas publik yang sangat jauh dibawah rata-rata yaitu Kota Magelang sebanyak 748 unit. Menurut Guttman fasilitas publik dapat mengidentifikasi pusat pertumbuhan wilayah, dengan demikian dapat ditentukan hierarki pusat-pusat pertumbuhan. Wilayah dengan fasilitas yang lebih lengkap merupakan pusat pelayanan, sedangkan wilayah dengan fasilitas kurang akan menjadi daerah belakang.

Prasarana fisik mempunyai peranan penting untuk menunjang berbagai kegiatan ekonomi dan sosial dalam meningkatkan pertumbuhan ekonomi, pemerataan dan kesejahteraan rakyat. Kegiatan operasi dan pemeliharaan prasarana dan sarana fisik ekonomi dan sosial seperti sekolah, puskesmas, jaringan jalan dan lain-lain mempunyai dampak terhadap perluasan lapangan kerja produktif (Adisasmita,2006:89). Ketidakmerataan penyebaran sumber daya dan pembangunan fasilitas sosial ekonomi menyebabkan pertumbuhan wilayah juga tidak merata, sehingga diperlukan adanya daerah-daerah yang dapat menjadi pusat pertumbuhan.

Secara geografis, pusat pertumbuhan adalah suatu lokasi yang banyak memiliki fasilitas dan kemudahan sehingga menjadi pusat daya tarik yang menyebabkan berbagai macam usaha tertarik untuk berlokasi didaerah tersebut, walaupun tidak ada interaksi antara usaha-usaha tersebut. Selain itu adanya konsentrasi geografis dari berbagai sektor atau fasilitas dapat menciptakan efisiensi di antara sektor-sektor yang saling membutuhkan dari kota tersebut. Orang yang datang ke kota tersebut bisa mendapatkan berbagai kebutuhan pada lokasi yang berdekatan. Jadi kebutuhan dapat diperoleh dengan lebih hemat waktu, biaya, dan tenaga. Hal ini membuat kota tersebut menarik untuk dikunjungi dan karena volume transaksi yang makin meningkat akan menciptakan economic of 
scale sehingga tercipta efisiensi lebih lanjut

(Tarigan, 2005).

Tabel 1. Jenis dan Jumlah Fasilitas Publik Provinsi Jawa Tengah Tahun 2013

\begin{tabular}{|c|c|c|c|}
\hline No & Kabupaten & $\begin{array}{c}\text { Jumlah Jenis Fasilitas } \\
\text { Publik }\end{array}$ & $\begin{array}{c}\text { Jumlah Unit } \\
\text { Fasilitas Publik }\end{array}$ \\
\hline 1 & Kab. Cilacap & 22 & 9.414 \\
\hline 2 & Kab. Banyumas & 22 & 8.976 \\
\hline 3 & Kab. Grobogan & 19 & 8.689 \\
\hline 4 & Kab. Brebes & 21 & 7.793 \\
\hline 5 & Kab. Klaten & 22 & 7.284 \\
\hline 6 & Kab. Magelang & 20 & 7.068 \\
\hline 7 & Kab. Demak & 19 & 7.044 \\
\hline 8 & Kab. Pati & 20 & 7.015 \\
\hline 9 & Kab. Kebumen & 21 & 6.897 \\
\hline 10 & Kab. Boyolali & 20 & 6.649 \\
\hline 11 & Kab. Pemalang & 23 & 6.627 \\
\hline 12 & Kab. Jepara & 22 & 6.597 \\
\hline 13 & Kab. Blora & 19 & 6.131 \\
\hline 14 & Kab. Semarang & 19 & 5.833 \\
\hline 15 & Kab. Kendal & 20 & 5.728 \\
\hline 16 & Kab. Banjarnegara & 19 & 5.704 \\
\hline 17 & Kab. Wonosobo & 22 & 5.704 \\
\hline 18 & Kota Semarang & 23 & 5.664 \\
\hline 19 & Kota Pekalongan & 23 & 5.653 \\
\hline 20 & Kab. Sragen & 21 & 5.491 \\
\hline 21 & Kab. Tegal & 21 & 5.295 \\
\hline 22 & Kab. Wonogiri & 19 & 5.245 \\
\hline 23 & Kab. Temanggung & 17 & 4.904 \\
\hline 24 & Kab. Purworejo & 20 & 4.596 \\
\hline 25 & Kab. Batang & 17 & 4.439 \\
\hline 26 & Kab. Karanganyar & 21 & 4.414 \\
\hline 27 & Kab. Rembang & 18 & 4.376 \\
\hline 28 & Kab. Pekalongan & 18 & 4.374 \\
\hline 29 & Kab. Sukoharjo & 22 & 4.335 \\
\hline 30 & Kab. Purbalingga & 20 & 4.271 \\
\hline 31 & Kab. Kudus & 20 & 3.993 \\
\hline 32 & Kota Surakarta & 20 & 2.283 \\
\hline 33 & Kota Tegal & 22 & 1.057 \\
\hline 34 & Kota Salatiga & 23 & 1.033 \\
\hline 35 & Kota Magelang & 22 & 748 \\
\hline \multicolumn{2}{|r|}{ Total } & & 191.324 \\
\hline \multicolumn{2}{|r|}{ Rata-rata } & & 5.466 \\
\hline
\end{tabular}

Sumber : BPS Provinsi Jawa Tengah (data diolah) 
Pemerintah Provinsi Jawa Tengah telah menetapkan kawasan-kawasan strategis yang tertuang dalam Peraturan Daerah Provinsi Jawa Tengah tahun 2003 tentang Rencana Tata Ruang Wilayah Provinsi Jawa Tengah 2003-2018 yang terdiri dari:

1. Kawasan Strategis Kedung Sepur (Kendal, Demak, Ungaran, Semarang, Purwodadi, dan Salatiga)

2. Kawasan Strategis Barlingmascakeb (Banjarnegara, Purbalingga, Banyumas, Cilacap, dan Kebumen)

3. Kawasan Strategis Purwomanggung (Purworejo, Wonosobo, Magelang, dan Temanggung)

4. Kawasan Strategis Subosukowonosraten (Surakarta, Boyolali, Sukoharjo, Karanganyar, Wonogiri, Sragen, dan Klaten)

5. Kawasan Strategis Banglor (Rembang dan Blora)

6. Kawasan Strategis Wanarakuti (Juwana, Jepara, Kudus, dan Pati)

7. Kawasan Strategis Tangkallangka (Batang, Pekalongan, Pemalang, dan Kajen)

8. Kawasan Strategis Bregas (Brebes, Tegal, dan Slawi)

Adanya penetapan kawasan-kawasan strategis tersebut diharapkan akan terjadi interaksi antar daerah sehingga dapat mengurangi kesenjangan antar daerah maupun antar wilayah di Provinsi Jawa Tengah.

Beberapa penelitian terdahulu yang meneliti mengenai fasilitas publik dan pusat pertumbuhan menggunakan analisis skalogram dilakukan oleh Bahadori, dkk. (2012), Ardila (2012), Rahayu dan Santoso (2014), Pratomo (2014), dan Utari (2015).

Bahadori, dkk. lebih fokus meneliti tentang ketimpangan fasilitas kesehatan di Provinsi Golestan, Iran Utara. Sedangkan Ardila
(2012), Rahayu dan Santoso (2014), Pratomo (2014) menambahkan alat analisis lain untuk mengetahui pusat pertumbuhan seperti Metode Gravitasi, Tipologi Klassen, Location Quotient (LQ), Model Rasio Pertumbuhan (MRP) dan Analisis Overlay.

\section{METODE PENELITIAN}

Jenis data yang digunakan dalam penelitian ini adalah data sekunder mengenai fasilitas publik di 35 kabupaten/kota Provinsi Jawa Tengah yang diperoleh dari BPS Provinsi Jawa Tengah tahun 2013. Data yang telah dikumpulkan kemudian dianalisis menggunakan analisis deskriptif melalui SPSS, dan analisis skalogram dan Indeks Sentralitas Marshal (ISM).

Metode pengumpulan data yang digunakan dalam penelitian ini adalah metode dokumentasi. Metode dokumentasi merupakan metode yang memperoleh data dengan mengumpulkan catatan-catatan yang diperlukan berupa softcopy maupun hardcopy, atau mengunduh dari website. Data softcopy dalam penelitian ini berupa dokumen arsip pemerintah yang diperoleh dari Badan Pusat Statistik.

\section{Metode Analisis Data}

Metode analisis data yang digunakan dalam penelitian ini adalah analisis statistik deskriptif untuk mengetahui tingkat kesenjangan fasilitas publik kabupaten/kota di Provinsi Jawa Tengah melalui tingkat penyebarannya (standar deviasi) yang diolah menggunakan SPSS dan untuk mengetahui pusat pertumbuhan disetiap kawasan strategis Provinsi Jawa Tengah penelitian ini menggunakan analisis skalogram dan indeks sentralitas marshal. Terdapat empat orde pusat pertumbuhan dalam analisis skalogram dan indeks sentralitas marshal yaitu:

Tabel 2. Orde Pusat Pertumbuhan

\begin{tabular}{lc|lc}
\hline \multicolumn{2}{c}{ Analisis Skalogram } & \multicolumn{2}{c}{ Indeks Sentralitas } \\
\hline Orde I & $>21.5-23$ & Orde I & $>118,24-146,95$ \\
Orde II & $>20-21.5$ & Orde II & $>89,54-118,24$ \\
Orde III & $>18.5-20$ & Orde III & $>60,84-89,54$ \\
Orde IV & $\geq 17-18.5$ & Orde IV & $\geq 32,14-60,84$ \\
\hline
\end{tabular}


Keterangan:

- Kabupaten/kota Orde I dengan jenis dan bobot fasilitas publik sangat tinggi

- Kabupaten/kota Orde II dengan jenis dan bobot fasilitas publik tinggi

- Kabupaten/kota Orde III dengan jenis dan bobot fasilitas publik sedang
- Kabupaten/kota Orde IV dengan jenis dan bobot fasilitas publik rendah

\section{HASIL DAN PEMBAHASAN}

Analisis Statistik Deskriptif

Tabel 3. Hasil Analisis Deskriptif Penyebaran Fasilitas Publik

\begin{tabular}{|c|c|c|c|c|c|}
\hline & $\mathrm{N}$ & Minimum & Maximum & Mean & Std. Deviation \\
\hline $\begin{array}{c}\text { Fas.Publik } \\
\text { Valid N }\end{array}$ & 35 & .39 & 4.92 & 2.8566 & 1.07332 \\
(listwise) & 35 & & & & \\
\hline
\end{tabular}

Sumber : Data Sekunder yang diolah, 2016

Hasil analisis deskriptif berdasarkan pada Tabel 1 menunjukkan bahwa total data yang digunakan $(\mathrm{N})$ sejumlah 35 dengan rasio fasilitas publik tertinggi sebesar 4,92\% pada Kabupaten Cilacap dan terendah sebesar 0,39\% pada Kota Magelang. Data statistik menunjukkan nilai rata-rata untuk rasio fasilitas publik sebesar 2,86\% dengan standar deviasi sebesar 1,07332\%. Nilai standar deviasi ini dibawah nilai rata-rata yang berarti bahwa kesenjangan antara nilai maksimum dengan nilai minimum fasilitas publik rendah.

\section{Analisis Skalogram dan Indeks Sentralitas}

Berdasarkan tabel 4 analisis skalogram dan Indeks Sentralitas diperoleh hasil Kota Semarang sebagai pusat pertumbuhan Kawasan Kedung Sepur erat kaitannya dengan Kota Semarang yang merupakan ibu kota Provinsi Jawa Tengah sehingga di kota ini banyak berkembang usaha atau aktivitas perekonomian masyarakat, baik itu usaha perdagangan dan jasa, industri kecil dan juga banyaknya pembangunan berbagai fasilitas ekonomi seperti pasar, terminal, warung makan dan sebagainya. Kota Semarang juga merupakan tempat konsentrasi penduduk dengan jumlah penduduk terbanyak diantara kabupaten/kota di Kawasan Kedung Sepur, yaitu 1,6 juta jiwa pada tahun 2013. Banyaknya jumlah penduduk di kota ini mengakibatkan kebutuhan masyarakat akan ketersediaan fasilitas sosial juga semakin meningkat, sehingga di kota ini banyak dibangun fasilitas pendidikan, kesehatan dan sarana peribadatan. Hal ini terlihat dari banyaknya jumlah fasilitas sosial di Kota Semarang, yaitu 5.664 unit, Oleh karena itu, kota ini dapat berfungsi sebagai kawasan pusat pertumbuhan yang penting dalam rangka memberikan pelayanan kepada masyarakat dan juga pengembangan wilayah lainnya di Kawasan Kedung Sepur. Sedangkan untuk Kota Salatiga sebagai salah satu pusat pertumbuhan di Kawasan Kedung Sepur erat kaitannya dengan posisi wilayah yang strategis karena berada di persimpangan Joglosemar (Jogja-SoloSemarang). Kondisi ini menjadikan Kota Salatiga kerap dilewati wisatawan.

Berkembangnya kegiatan pariwisata di Kota Salatiga memicu pembanguan fasilitas publik di Kota Salatiga untuk memenuhi kebutuhan para wisatawan. 
Tabel 4. Pusat Pertumbuhan Provinsi Jawa Tengah berdasarkan Kawasan Strategis

\begin{tabular}{|c|c|c|c|c|}
\hline \multirow{2}{*}{ Kawasan } & \multicolumn{2}{|c|}{ Skalogram } & \multicolumn{2}{|c|}{ Indeks Sentralitas } \\
\hline & Kab/Kota & Orde & Kab/Kota & Orde \\
\hline \multirow[t]{2}{*}{ Kedung Sepur } & Kota Semarang & I & Kota Semarang & I \\
\hline & Kota Salatiga & I & & \\
\hline \multirow{2}{*}{ Barlingmascakep } & Banyumas & I & Banyumas & II \\
\hline & Cilacap & I & Cilacap & II \\
\hline \multirow[t]{2}{*}{ Purwomanggung } & Wonosobo & I & & \\
\hline & Kota Magelang & I & & \\
\hline \multirow[t]{2}{*}{ Subosukowonosraten } & Sukoharjo & I & Klaten & I \\
\hline & Klaten & I & & \\
\hline Banglor & Blora & III & Blora & III \\
\hline Wanarakuti & Jepara & $\mathrm{I}$ & Jepara & III \\
\hline Tangkallangka & $\begin{array}{l}\text { Kota Pekalongan } \\
\text { Pemalang }\end{array}$ & $\begin{array}{l}\text { I } \\
\text { I }\end{array}$ & & \\
\hline Bregas & Tegal & I & & \\
\hline
\end{tabular}

Banyak hal yang menjadi alasan Kabupaten Banyumas menjadi pusat pertumbuhan di Kawasan Barlingmascakep, letak geografis kabupaten karena berada pada jalur yang menghubungkan antarwilayah. Selain itu, Banyumas memiliki 15 jenis bahan galian yang berpotensi sebagai peluang investasi. Dengan kapasitas produksi /cadangan yang ada, dan fasilitas pendukung lainnya, maka potensi bahan galian di Kabupaten Banyumas mempunyai peluang investasi yang cukup menjanjikan. Hal tersebut menyebabkan permintaan fasilitas publik di Kabupaten Banyumas meningkat. Selain itu, Kabupaten Banyumas merupakan salah satu dengan jumlah penduduk terbanyak, yaitu 1,6 juta jiwa pada tahun 2013 sehingga kebutuhan akan ketersediaan fasilitas publik besar. Hal ini dapat terlihat dari jumlah fasilitas di Kabupaten Banyumas , yaitu sebanyak 8.976 unit. Sedangkan Kabupaten Cilacap sebagai pusat pertumbuhan di Kawasan Barligmascakep erat kaitannya dengan sektor pertambangan yang hampir tersebar merata diseluruh kecamatan di Kabupaten Cilacap. Potensi tersebut dapat mengundang adanya peluang investasi yang menuntut tersedianya fasilitas publik yang lengkap. Kabupaten Cilacap merupakan salah satu daerah konsentrasi penduduk, pada tahun 2013 mencapai 1,68 juta jiwa. Sehingga di kabupaten ini banyak dibangun fasilitas publik terlihat dari jumlah fasilitas Kabupaten Cilacap yang mencapai 9.414 unit. jumlah tersebut merupakan jumlah fasilitas terbanyak di Kawasan Barlingmascakep bahkan di Provinsi Jawa Tengah.

Potensi pertanian di Kabupaten Wonosobo menjadi salah satu alasan Kabupaten Wonosobo menjadi pusat pertumbuhan di Kawasan Purwomanggung. Pertanian tanaman pangan memiliki andil besar dengan komoditasnya meliputi tanaman padi dan palawija, tanaman sayuran dan tanaman buahbuahan. Kawasan pertanian identik dengan kawasan pedesaan yang masih kuat dengan semangat gotong royong dan keagamaannya, hal tersebut membuat banyak pembangunan fasilitas publik terutama fasilitas peribadatan yaitu sejumlah 3.977 unit fasilitas ibadah dan 299 pesantren yang merupakan jumlah terbanyak di Kawasan Purwomanggung. Sedangkan Kota Magelang sebagai pusat pertumbuhan di Kawasan Purwomanggung erat kaitannya dengan Kota Magelang sebagai ibukota Karesidenan Kedu sehingga di kota ini banyak berkembang usaha dan aktivitas perkonomian masyarakat sehingga banyak pembangunan fasilitas publik dikota ini. Selain itu, banyak industri yang berkembang di kota ini, salah satunya industri tekstil. Hasil produksi dari industri ini banyak dimanfaatkan untuk industri konveksi di berbagai daerah, seperti Kabupaten Sukoharjo, dan Kabupaten Klaten. Pariwisata di Kota Magelang juga cukup berkembang, salah 
satunya adalah Candi Borobudur, Museum Sudirman, Museum Diponegoro, dan sebagainya. Berkembangnya industri-industri dan kegiatan pariwisata mengakibatkan kebutuhan akan fasilitas publik meningkat.

Kabupaten Klaten sebagai pusat pertumbuhan di Kawasan Subosukowonosraten berhubungan dengan potensi industri yang terus berkembang dikabupaten ini. Salah satunya adalah industri tekstil, industri mebel, dan industri logam. Kerajinan Pande Besi merupakan salah satu potensi unggulan di Kabupaten Klaten. Produk utama UMKM ini adalah dalam bidang alat-alat pertanian seperti cangkul, skop, sabit, palu, linggis, garpu, gembor, dan lain-lain. Kedua adalah dalam bidang alat-alat rumah tangga seperti lampu, kompor, tenpat kerupuk dan lain sebagainya. Pengrajin Pande besi di Kabupaten Klaten tersebar di Segaran Kecamatan Delanggau dan Padas Karanganom Klaten. Banyaknya aktivitas ekonomi tersebut meningkatkan pembangunan fasilitas publik. Selain itu, Kabupaten Klaten merupakan daerah dengan jumlah penduduk terbanyak di Kawasan Subosukowonosraten yang mencapai 1,14 juta jiwa pada tahun 2013. Hal tersebut memicu pembangunan fasilitas publik di daerah ini yang mencapai 7.284 unit. Jumlah tersebut merupakan jumlah terbanyak di Kawasan Subosukowonosraten. Banyaknya sentra industri kerajinan di Kabupaten Sukoharjo menjadi salah satu alasan Kabupaten Sukoharjo menjadi pusat pertumbuhan di Kawasan Subosukowonosraten. Terdapat industri shuttlecock yang memproduksi 400 ribu lusin/lebih pertahun, kemudian adanya industri pembuatan gitar, industri mebel kayu dan rotan, industri tenun, dan sebagainya.

Bidang pertambangan menjadi salah satu alasan Kabupaten Blora merupakan pusat pertumbuhan di Kawasan Banglor. Kabupaten Blora merupakan satu-satunya kabupaten/kota di Jawa Tengah yang memiliki potensi pertambangan migas (minyak dan gas). Pertambangan migas terletak di Kecamatan Cepu, dimana potensi tersebut mendorong pemerintah untuk mendirikan Perguruan Tinggi Kedinasan (PTK) STEM Migas Cepu dengan harapan Blora mampu mewujudkan model pendidikan yang mengakomodir kebutuhan tenaga kerja dibidang permigasan. Selain migas dalam sektor petambangan, Kabupaten Blora juga mempunyai potensi sumber daya alam yang cukup besar. Potensi bahan baku batu marmer, batu onix dan batu kapur. Kerajinan batu onix sudah mulai dikembangkan sejak tahun 2008. Kegiatan-kegiatan pertambangan tersebut memicu kebutuhan akan fasilitas publik meningkat, sehingga dibangun banyak fasilitas di Kabupaten Blora.

Kabupaten Jepara terkenal dengan sebutan Kota Ukir. Terdapat banyak sentra kerajinan ukiran kayu yang telah banyak diekspor. Hal tersebut menjadi salah satu alasan Kabupaten Jepara sebagai pusat pertumbuhan di Kawasan Wanarakuti. Kerajinan ukir ini tersebar hampir keseluruh kawasan di Kabupaten Jepara. Hal ini memicu kebutuhan akan fasilitas terutama fasilitas ekonomi meningkat. Sedangkan Kabupaten Pati sebagai pusat pertumbuhan di Kawasan Wanarakuti erat kaitannya dengan potensi pertanian yang ada di kabupaten tersebut. Terdapat sentra buah jambu monyet, buah manggis, padi dan kacang hijau. Selain itu, terdapat industri-industri kecil seperti industri tepung tapioka, industri kain batik dan industri batu bata. Berkembangnya pertanian dan industri-industri kecil berdampak pada meningkatnya kebutuhan akan fasilitas-fasilitas ekonomi. Selain itu, Kabupaten Pati merupakan daerah konsentrasi penduduk di Kawasan Wanarakuti, pada tahun 2013 sebanyak 1,22 juta jiwa yang memicu meningkatnya kebutuhan akan fasilitas publik, sehingga di Kabupaten Pati banyak dibangun fasilitas-fasilitas publik yaitu sebanyak 7.015 unit pada tahun 2013

Kota Pekalongan sebagai pusat pertumbuhan di Kawasan Tangkallangka erat kaitannya dengan julukan kota tersebut yaitu Kota Batik. Terdapat banyak sentra batik di kota ini. Sentra utama pembuatan batik berada di Kampung Kauman dan Besindon. Selain batik, terdapat budidaya ikan tambak yang setiap tahunnya memproduksi ratusan ribu ton ikan. Budidaya ikan ini berpusat di tiga kecamatan yaitu Kecamatan Tirto, Kecamatan Wonokerto, dan kecamatan Siwalan. Berkembangnya 
kegiatan usaha dan aktivitas ekonomi tersebut meningkatkan pembangunan fasilitas-fasilitas publik Sedangkan Kabupaten Pemalang sebagai pusat pertumbuhan di Kawasan Tangkallangka karena memiliki sumber daya alam yang potensial. Terdapat area tambang dikawasan Gunung Slamet berupa Diorit, Kaolin, Batu Gamping, dan Batu Marmer. Terdapat industriindustri pakaian jadi dan konveksi, industri tenun. Di sektor pertanian terdapat komoditas yang menonjol yaitu padi, ketela pohon dan jagung serta buah-buahan berupa Nanas Batu, pisang dan manga. Kabupaten Pemalang merupakan daerah konsentrasi penduduk dengan jumlah penduduk terbanyak di Kawasan Tangkallangka, yaitu 1,28 juta jiwa pada tahun 2013 sehingga banyak dibangun fasilitas publik didaerah ini. Hal ini terlihat dari jumlah fasilitas publik yang mencapai 6.627 unit. Jumlah tersebut merupakan jumlah terbanyak di Kawasan Tangkallangka.

Hasil analisis skalogram dan ISM menunjukkan daerah yang berpotensi menjadi pusat petumbuhan di kawasan Bregas adalah Kota Tegal. Produk industri logam merupakan potensi unggulan di Kota Tegal. Pengusaha industri logam berskala menengah maupun kecil mengelompok di Kecamatan Tegal Timur, Kecamatan Tegal Barat, dan Tegal Selatan. Daerah kota identik dengan kawasan yang telah modern dengan jenis fasilitas yang beragam termasuk Kota Tegal. Pembangunan fasilitas di Kota Tegal berkembang dengan potensi-potensi yang dimiliki oleh kota tersebut. Kota Tegal memiliki 22 jenis dari 23 jenis fasilitas dalam penelitian.

\section{SIMPULAN}

Berdasarkan hasil penelitian yang dilakukan terhadap 35 kabupaten/kota Provinsi Jawa Tengah pada tahun 2013 dapat diketahui bahwa tingkat kesenjangan fasilitas Provinsi Jawa Tengah rendah. Pusat pertumbuhan di masing-masing kawasan strategis Provinsi Jawa Tengah adalah Kawasan Kedung Sepur: Kota Semarang dan Kota Salatiga, Kawasan Barlingmascakep: Kabupaten Cilacap dan Kabupaten Banyumas, Kawasan
Purwomanggung: Kota Magelang dan Kabupaten Wonosobo, Kawasan Subosukowonosraten: Kabupaten Sukoharjo dan Kabupaten Klaten, Kawasan Banglor: Kabupaten blora, Kawasan Wanarakuti: Kabupaten Jepara dan Kabupaten Pati, Kawasan Tangkallangka: Kota Pekalongan dan Kabupaten Pemalang, Kawasan Bregas: Kota Tegal.

\section{DAFTAR PUSTAKA}

Adisasmita, Rahardjo. 2006. Pembangunan Pedesaan dan Perkotaan. Yogyakarta: Graha Ilmu

Ardila, Refika. 2012. Analisis Pengembangan Pusat Pertumbuhan Ekonomi di Kabupaten Banjarnegara. Economic Development Analysis Journal, Vol. 1, No. 2, Hal. 1-9

Badan Pusat Statistik. 2014. Jawa Tengah dalam Angka Tahun 2014. BPS Jawa Tengah. Jawa Tengah

Bahadori, M.,et al. 2012. Classification of Health Structural Indicator Using Scalogram Model in Golestan Province, Northern Iran. Iranian $J$ Publ Health, Vol. 41, No. 5, Hal. 58-65.

Jawa Tengah. Peraturan Daerah Provinsi Jawa Tengah tentang Rencana Tata Ruang Wilayah Provinsi Jawa Tengah 2003-2018. Perda No. 21 Provinsi Jawa Tengah Tahun 2003

Kuncoro, Mudrajad. 2006. Ekonomika Pembangunan Teori, Masalah, dan Kebijakan. Yogyakarta : UPP STIM YKPN

Pratomo, Aziz. 2014. Analisis Potensi Pengembangan Pusat Pertumbuhan Ekonomi di Kabupaten Cilacap. Economic Development Analysis Journal, Vol. 3, No. 1, Hal. 13-27

Rahayu, Eta dan Eko Budi Santoso. 2014. Penentuan Pusat-Pusat Pertumbuhan dalam Pengembangan Wilayah di Kabupaten Gunungkidul. Jurnal Teknik Pomits, Vol. 3, No. 2, Hal. 290-295

Tarigan, Robinson. 2005. Ekonomi Regional Teori dan Aplikasi, Jakarta: Bumi Aksara.

Todaro M, P. 2006. Pembangunan Ekonomi di Dunia Ketiga. Jakarta: Erlangga

Utari, MG Endang Sri. 2015. Analisis Sistem Pusat Pelayanan Pemukiman di Kota Yogyakarta Tahun 2014. Journal of Economic and Policy, Vol. 8, No. 1, Hal 62-72. 